\title{
Pemilihan Karir Perempuan Sebagai Akuntan Pendidik Dalam Perspektif Simone de Beauvoir: Studi Kasus pada Akuntan Pendidik Jurusan Akuntansi Fakultas Ekonomi dan Bisnis Universitas Tanjungpura Pontianak
}

\author{
Soraya* \\ Politeknik Negeri Pontianak \\ Zulham Al Farizi \\ Politeknik Negeri Pontianak
}

\begin{abstract}
Educators accountants have a significant role in the education world. This paper aims to gain a better understanding and in-depth information on the aspects that make up the women's options for a career as an accountant educators. Further goal is to explaining the selection of women's careers as educators accountant in perspective Simone de Beauvoir. This paper used a qualitative approach. Researcher also conducted narrative researchers through in-depth interviews to the 7 (seven) women in the Department of Accounting Faculty of Economics and Business, University of Tanjungpura Pontianak. From the interviews, founded are six aspects that make up the women's options for a career as an accountant educators. These six aspect are the job opportunity (vacancies), time work flexibility, family background, meeting many people (students), childhood dream, and knowledge sharing. From these six aspect of the career choice, job opportunity (vacancies) and time flexibility aspect are the most disclosed widely aspect in choosing a career as an accountant educators. In addition, Simone de Beauvoir perspective can not explain the selection of women's careers as educators accountant.
\end{abstract}

Keywords: Career choice, qualitative, educators accountants, Simone de Beauvoir

\section{PENDAHULUAN}

Dalam era globalisasi, dunia usaha dan masyarakat telah menjadi semakin kompleks sehingga menuntut adanya perkembangan berbagai disiplin ilmu termasuk akuntansi. Keadaan ini menjadikan akuntan sebagai suatu profesi yang sangat dibutuhkan keberadaannya dalam lingkungan organisasi bisnis (Hadi, 2011). Akuntansi merupakan salah satu jurusan di Fakultas Ekonomi yang banyak diminati mahasiswa saat

\footnotetext{
* Korespondensi: Soraya, Jurusan Akuntansi, Politeknik Negeri Pontianak, Jalan A. Yani, Pontianak 78124, Indonesia. Alamat Email: sorayaponti@gmail.com.
} 
ini. Hasil penelitian Ariani (2004) menyebutkan bahwa rata-rata mahasiswa memilih jurusan akuntansi didorong oleh keinginan mereka untuk menjadi profesional di bidang akuntansi. Hal ini membawa pada suatu konsekuensi bahwa masih terbuka lebar bagi setiap orang untuk memasuki profesi akuntan, sehingga profesi akuntan merupakan salah satu pilihan karir yang menjanjikan (Oktavia, 2005).

Penelitian ini menitikberatkan pada profesi akuntan pendidik sebagai pilihan karir para perempuan. Ketertarikan ini didasarkan pada pendapat Widhinugroho (dalam Rasmini, 2007) bahwa secara global pengajaran akuntansi di perguruan tinggi cenderung mengarahkan mahasiswa untuk bekerja sebagai akuntan publik. Namun, dalam pemilihan karir jangka panjang, khususnya perempuan, lebih banyak memilih berkarir sebagai akuntan pendidik. Hal ini didasarkan pada fenomena yang terdapat di Universitas Tanjungpura, khususnya pada Fakultas Ekonomi dan Bisnis Jurusan Akuntansi. Terdapat sebelas orang akuntan pendidik perempuan pada Jurusan Akuntansi dan satu orang diantaranya juga berprofesi sebagai auditor internal pada BPD Provinsi Kalimantan Barat atau 44\% dari jumlah keseluruhan akuntan pendidik. Selain itu, jumlah perempuan yang memilih berkarir sebagai akuntan pendidik mengalami peningkatan dari tahun ke tahun.

Akuntan pendidik sebagai salah satu bagian dari profesi akuntan memiliki peranan yang cukup besar dalam menentukan perkembangan sumber daya manusia di masa mendatang. Khomsiyah dan Indriantoro (dalam Hastuti, 2007) menyatakan bahwa pendidikan akuntansi mempunyai pengaruh besar pada perilaku etis akuntan. Pendidikan akuntansi tidak saja bertanggung jawab pada pengajaran ilmu pengetahuan bisnis dan akuntansi (transformasi ilmu pengetahuan), akan tetapi juga mendidik mahasiswanya agar mempunyai kepribadian yang utuh sebagai manusia. Cohen, Pant dan Sharp (1998) yang meneliti pengaruh gender terhadap perilaku etika membuktikan bahwa adanya perbedaan intensitas dan orientasi etika antara laki-laki dan perempuan praktisi akuntan maupun non-akuntan. Berdasarkan temuan di atas, peneliti menganggap bahwa perempuan yang berprofesi sebagai akuntan pendidik memiliki peran yang sangat penting dalam dunia pendidikan. Selain itu, akuntan pendidik merupakan starting point dalam menciptakan akuntan-akuntan profesional yang berperilaku etis.

Teori yang menjadi dasar penelitian ini adalah mengacu pada filsafat feminis eksistensialis Simone de Beauvoir karena menurut Tong (2010) tidak ada pengantar terhadap pemikiran feminis yang dapat dikatakan lengkap, jika tidak melibatkan telaah tentang karya ini, yang telah menolong banyak feminis untuk memahami betapa pentingnya ke-liyanan perempuan. Penelitian ini berusaha untuk menjawab beberapa pertanyaan sebagai berikut: (1) Aspek-aspek apa sajakah yang membentuk pilihan perempuan untuk berkarir sebagai akuntan pendidik? (2) Bagaimana perspektif Simone de Beauvoir dapat menjelaskan pemilihan karir perempuan sebagai akuntan pendidik? 


\section{TINJAUAN PUSTAKA}

\subsection{Pendekatan Sosiologi Akuntansi}

Pendekatan akuntansi normatif maupun positif sampai saat ini masih mendominasi penelitian akuntansi. Artikel-artikel yang terbit pada jurnal bergengsi seperti The Accounting Review, Journal of Accounting Research, dan Journal of Management Accounting Research hampir sebagian besar menggunakan pendekatan mainstream akuntansi positif dengan ciri khas menggunakan model matematis dan pengujian hipotesis secara statistik. Pendekatan ini pada dasarnya tidak mempercayai dasar filosofi yang digunakan oleh pengikut mainstream positif. Sebagai gantinya, pendekatan positif meminjam metodologi dari ilmu-ilmu sosial yang lain seperti filsafat, sosiologi, dan antropologi untuk memahami akuntansi dan pendekatan ini sering disebut pendekatan sosiologi akuntansi (Ghozali, 2007). Tujuan dari sosiologi adalah mendapatkan pengetahuan tentang sifat organisasi manusia agar dapat menginterpretasikan bagaimana dan mengapa kejadian sosial itu terjadi (Turner, 1986). Paradigma yang diajukan dari pemikiran akuntansi ini salah satunya adalah paradigma interpretif. Metode kualitatif lebih cocok untuk pendekatan interpretif (Triyuwono, 2000). Paradigma interpretif berasal dari tradisi fenomenologi yang memfokuskan pada observasi mendalam terhadap situasi tertentu dengan harapan memperoleh pemahaman mendalam dari pengalaman sehari-hari akuntansi dan akuntan.

Beberapa hasil penelitian dengan pendekatan interpretif antara lain Ansari dan Euske (1987) yang melakukan penelitian lapangan jangka panjang dengan menggunakan in-depth interview, archival data dan observasi fisik terhadap penggunaan data akuntansi biaya pada lembaga militer. Hasil penelitian menunjukkan bahwa sistem akuntansi biaya adalah dinamis sepanjang waktu, berubah dari satu model informasi ke model informasi yang lain dan menciptakan pengguna baru untuk informasi yang dihasilkan. Colignon dan Covaleski (1988) melakukan studi kasus dengan metode interview, observasi dan dokumentasi untuk menginvestigasi akuntansi manajemen sebagai suatu proses. Mereka menyimpulkan bahwa akuntansi manajemen adalah proses dinamis yang melibatkan saling penyesuaian yaitu mengubah dan diubah oleh organisasi.

Chariri (2006) menyatakan pelaporan keuangan kenyataannya dipandang sebagai suatu praktik kelembagaan dan politik yang melibatkan institusi dan pelaku-pelaku yang kuat. Untuk memahami praktik semacam ini, maka perlu menyertakan pemahaman tentang aspek-aspek kelembagaan dan perilaku pelaku tersebut, karena aspek-aspek kelembagaan dan perilaku dapat membangun sebuah realitas praktik pelaporan keuangan. Namun, lembaga dan perilaku pelaku tersebut dibentuk oleh aspek budaya dan konstruksi sosial. Hal ini dapat meningkatkan studi sosiologi akuntansi, mengembangkan pemahaman pengetahuan akuntansi dan praktik dalam konteks sosial, politik, kelembagaan dan budaya serta memberikan kontribusi bagi penelitian lain dalam berbagai disiplin ilmu. Dari penjelasan di atas, dapat dikatakan bahwa penelitian mengenai pemilihan karir perempuan sebagai akuntan pendidik dalam perspektif Simone de Beauvoir ini merupakan penelitian di bidang akuntansi. Penelitian ini dilakukan 
secara empiris melalui proses interaksi sosial dengan para perempuan yang memilih berkarir sebagai akuntan pendidik.

\subsection{Karir}

Karir berasal dari bahasa Belanda yaitu carriere, yang diterjemahkan sebagai perkembangan dan kemajuan dalam pekerjaan seseorang. Ini juga bisa berarti jenjang dalam sebuah pekerjaan tertentu. Dalam Kamus Besar Bahasa Indonesia, karir diartikan sebagai perkembangan dan kemajuan di kehidupan pekerjaan, jabatan, dan sebagainya, atau karir adalah pekerjaan yang memberikan harapan untuk maju (Aminah, 2010). Surya (1988) menegaskan bahwa karir erat kaitannya dengan pekerjaan, tetapi mempunyai makna yang lebih luas dari pada pekerjaan. Karir dapat dicapai melalui pekerjaan yang direncanakan dan dikembangkan secara optimal dan tepat, tetapi pekerjaan tidak selamanya dapat menunjang pencapaian karir. Dengan demikian pekerjaan merupakan tahapan penting dalam pengembangan karir.

Dalam bagian lain juga disebutkan bahwa karir adalah gaya hidup. Artinya bahwa karir adalah suatu makna utama dari ekspresi kemampuan dan minat khusus yang secara intensif disadari sebagai implikasi dari pilihan pekerjaan untuk gaya hidup di masa mendatang. Dalam diskusi tentang karir sebagai gaya hidup, isu-isu yang berlawanan dengan nilai-nilai pekerjaan yang menyenangkan sering kali muncul. Atas dasar ini karir hakekatnya adalah bagaimana memadukan antara kemampuan dengan nilai kesenangan sebagai satu kesatuan. Hoyt (Gibson dan Mitchell, 1995) menjelaskan bahwa karir adalah totalitas dari pengalaman pekerjaan/jabatan seseorang dalam sepanjang hidupnya. Pemilihan karir juga dipengaruhi oleh keyakinan pribadi seseorang. Dalam teori tindakan beralasan (Theory of Reasoned Action/TRA), keyakinan pribadi seseorang adalah faktor penentu penting dari tindakan masa depan (Ajzen, 1991).

Menurut Holland, 1985 (dalam Putri, 2012) bahwa penting membangun keterkaitan atau kecocokan antara tipe kepribadian individu dan pemilihan karir tertentu. Holland (1985) mengajukan enam tipe kepribadian dasar yang berhubungan dengan karir yaitu intelektual, realistik, sosial, konvensional, enterpise, dan artistic. Tipe sosial cenderung memiliki orientasi menolong. Mereka tampaknya memiliki modal paling baik untuk memasuki profesi "yang berhubungan dengan orang" seperti mengajar, pekerja sosial, konseling dan semacamnya. Tipe sosial ini juga memiliki tingkat prestise yang tinggi.

Sedangkan menurut Gibson dan Mitchell (1995) bahwa pilihan karir lebih berhubungan dengan kesempatan dari pada sesuatu yang sengaja direncanakan. Bagi beberapa orang, bekerja merupakan dasar harga diri dan kebanggaan. Bagi sejumlah orang lainnya bekerja dianggap sebagai prestise yang diperoleh, tempat untuk melakukan partisipasi sosial atau sebagai sumber kesenangan intrinsik atau merupakan ekspresi dari pribadi yang kreatif dan juga merupakan cara memanfaatkan waktu dengan cara yang rutin menyenangkan (Putri, 2012). Menurut Benny, Ellya dan Yuskar (2006) karier 
merupakan suatu keahlian atau profesional seseorang di bidang ilmunya yang dinilai berdasarkan pengalaman kerja yang akan memberikan kontribusi kepada organisasi.

\subsection{Akuntan Pendidik}

Undang-undang No. 14/2005 tentang "Guru dan Dosen" menyebutkan bahwa dosen adalah pendidik profesional dan ilmuwan dengan tugas utama mentransformasikan, mengembangkan, dan menyebarluaskan ilmu pengetahuan, teknologi, dan seni melalui pendidikan, penelitian, dan pengabdian kepada masyarakat. Soemarso (2004) menyatakan akuntan pendidik adalah akuntan yang bertugas dalam pendidikan akuntansi, yaitu mengajar, menyusun kurikulum pendidikan akuntansi dan melakukan penelitian di bidang akuntansi.

Akuntan pendidik dalam melaksanakan tugasnya berpedoman pada Tri Dharma perguruan tinggi, yaitu pengajaran, penelitian, dan pengabdian kepada masyarakat. Pengajaran merupakan tugas utama seorang pendidik, pengajaran dilakukan dengan tatap muka di kelas, proses pengajaran diharapkan menjadi sarana untuk mentransfer ilmu pengetahuan dan pendidikan pada anak didiknya. Tugas penelitian juga merupakan tugas dari seorang akuntan pendidik, sehingga disamping melakukan pekerjaan mengajar, seorang pendidik juga dituntut untuk mampu melakukan penelitian sebagai sarana untuk menerapkan ilmu dalam praktek yang sesungguhnya. Selain itu, akuntan pendidik juga harus mampu melaksanakan pengabdian kepada masyarakat, hal ini dimaksudkan agar seorang pendidik tidak hanya mampu berkomunikasi dengan bidang ilmunya sendiri, namun juga harus mampu berkomunikasi dengan masyarakat luas (Setiyani, 2005).

Akuntan pendidik harus dapat melakukan transfer knowledge kepada mahasiswanya, memiliki tingkat yang tinggi dan menguasai pengetahuan bisnis dan akuntansi, teknologi informasi dan mampu mengembangkan pengetahuannya melalui penelitian (Oktavia, 2005). Hasil penelitian menunjukkan bahwa akuntan pendidik mempunyai jaminan hari tua (Cangelosi, Condi, dan Luthy, 1985). Akuntan pendidik mempunyai keamanan kerja yang terjamin dan akuntan pendidik mempunyai pekerjaan yang sifatnya rutin sehingga tidak mengalami kesulitan untuk melakukan pekerjaan sehari-hari. Akuntan pendidik sebagai salah satu bagian dari profesi akuntan memiliki peranan yang cukup besar dalam menentukan perkembangan sumber daya manusia di masa mendatang (Rahayu, Sudaryono, dan Setiawan, 2003). Untuk itu, peningkatan mutu dari akuntan pendidik secara tidak langsung juga akan berpengaruh pada peningkatan kualitas sumber daya manusia di masa mendatang dan juga perkembangan akuntansi sebagai satu bidang ilmu (SNA III, 2000).

\subsection{Pemilihan Karir Perempuan dalam Perspektif Simone de Beauvoir}

Simone de Beauvoir (1908-1986) lahir tanggal 9 Januari 1908 di 103 Boulevard du Montparnasse, Prancis. Di kalangan para aktivis gender, Simone de Beauvoir 
merupakan salah satu tokoh yang harus ditelaah. Karyanya, "Le Deuxieme Sexe" (1949) atau The Second Sex dicatat sebagai karya klasik yang memberikan penerangan tentang ketertindasan perempuan selama ini dan telah mendorong inspirasi gerakan-gerakan pembebasan perempuan. Secara umum pemikiran dari Simone de Beauvoir merupakan kajian teori feminisme. Menurut Tong (2010) dalam perkembangan sejarahnya teori feminisme memiliki berbagai jenis aliran seperti feminisme liberal, feminisme radikal, feminisme sosialis, feminisme psikoanalisis, feminisme eksistensialis, feminisme postmodern, feminisme multikultural dan ekofeminisme. Teori Simone de Beauvoir sendiri tergolong ke dalam teori filsafat feminism 10 eksistensialis.

Menurut Imbert (dalam Grosholz, 2004) eksistensialisme merupakan suatu gerakan filosofis yang mempelajari pencarian makna seseorang dalam keberadaannya (eksistensinya). Manusia yang eksis adalah manusia yang terus berusaha mencari makna dalam kehidupannya. Karena berbicara mengenai makna, eksistensialisme tidak memperlakukan individu sebagai sekedar konsep, melainkan menghargai subjektivitas individu jauh melampaui objektivitasnya. Eksistensialisme dari Beauvoir akan lebih terasa apabila mengutip suatu kalimat "One is not born, but rather becomes a woman". Maksudnya, perempuan (sebagai jenis kelamin) bukan sekedar ditentukan ketika lahir tapi justru karena pembagian peran dalam masyarakat. Dari kalimat tersebut dapat dimaknai bahwa gender merupakan suatu proses menjadi, karena itu mengandung makna pilihan dan perubahan (choice and change). Oleh karena proses menjadi adalah sebuah pilihan, pada akhirnya de Beauvoir memilih untuk tidak menikah meskipun Sartre pernah melamarnya. Menurut de Beauvoir, perempuan tidak akan pernah bisa merebut eksistensi dirinya, apabila ia selalu diletakkan sebagai objek untuk yang lain.

Pemilihan karir perempuan sebagai akuntan pendidik dalam perspektif Simone de Beauvoir meliputi beberapa aspek, yaitu: (1) Women as Other. De Beauvoir (1956) berargumentasi bahwa perempuan diopresi melalui ke-liyanannya (otherness). Perempuan adalah liyan (the Other) karena perempuan bukanlah laki-laki. Laki-laki adalah bebas. Makhluk yang menentukan dirinya sendiri yang mendefinisi makna eksistensinya. Perempuan adalah liyan (the Other), objek yang tidak menentukan makna eksistensinya sendiri. Jika perempuan ingin menjadi Diri, suatu subjek, seperti juga lakilaki, perempuan harus mentransendensi definisi, label, dan esensi yang membatasi eksistensinya. Perempuan harus menjadikan dirinya sebagaimana yang diinginkannya. (2) Independent Women berarti kebebasan perempuan, dalam arti eksistensialis, adalah didasarkan pada pengambilan tanggung jawab seorang individu untuk apa dia hidup. Hal ini dicapai ketika seorang individu mampu "melampaui apa yang sudah diberikan untuk menghadapi masa depan". (3) Institution of Work. Organisasi adalah tempat di mana banyak disebarluaskan image gender yang diciptakan dan direproduksi (Acker, 1992). (4) Institution of Motherhood. De Beauvoir (dalam Simons dan Benyamin, 1979) berkomentar bahwa kehamilan membuat perangkap bagi perempuan yang berusaha untuk menjadi mandiri dan mengubah mereka menjadi budak. Meskipun bukan tidak 
mungkin bagi seorang perempuan untuk menjadi seorang ibu dan menjadi peran lain di luar pengertian manusia biasa tetapi hal ini sangat sulit.

\subsection{Telaah Penelitian Sebelumnya}

Ada beberapa penelitian sebelumnya yang berkaitan dengan penelitian ini. Namun, penelitian tersebut lebih banyak meneliti tentang pilihan karir perempuan sebagai manajer dan akuntan publik. Masih sedikit sekali studi-studi yang meneliti pilihan karir perempuan sebagai akuntan pendidik. Secara singkat, penelitian terdahulu tentang pilihan karir dapat dilihat dalam Tabel 1.

Ahmadi, Helms, dan Nodoushani (1995) melakukan penelitian dengan pendekatan kuantitatif terhadap 214 akuntan publik dengan mengirimkan kuesioner yang terdiri atas 27 aspek terhadap pilihan pekerjaan sebagai akuntan, baik laki-laki maupun perempuan. Dengan melakukan uji-t dan analisis faktor ditemukan bahwa perbedaan signifikan antara akuntan laki-laki dan perempuan diperoleh dari aspek pengalaman dan gaji. Pengalaman laki-laki lebih lama daripada pengalaman perempuan (14,6 tahun dibanding 8,6 tahun) dan gaji laki-laki lebih tinggi daripada gaji perempuan $(\$ 49,000$ dibanding \$36,000). Analisis faktor menunjukkan bahwa aspek perkembangan karir merupakan faktor utama bagi akuntan perempuan, sementara fleksibilitas merupakan faktor terakhir. Bahkan, isu keluarga sama sekali tidak memberikan kontribusi yang signifikan dalam proses pilihan karir. Akuntan laki-laki lebih berfokus pada aspek pengaruh lingkungan dalam melakukan pilihan pekerjaan. Sedangkan, aspek gaji bukan merupakan aspek penting dalam memilih pekerjaan.

Twomey, Linehan dan Walsh (2002) melakukan interview terhadap 24 akuntan muda generasi $\mathrm{X}$ di Irlandia, yang terdiri dari 12 akuntan laki-laki dan 12 akuntan perempuan yang berumur di bawah 30 tahun. Dengan pendekatan kualitatif, penelitian ini bertujuan untuk membuktikan pengaruh gender di dalam praktek akuntansi profesional atau di dalam industri. Hasil penelitian menunjukkan bahwa adanya hubungan negatif antara tata kelola organisasi dengan akuntan perempuan. Khususnya, ditemukan bahwa akuntan perempuan muda mengalami hambatan karir karena rekanrekan pria mendominasi struktur tata kelola organisasi.

Tyler (2005) melakukan penelitian dengan pendekatan kualitatif melalui review teks manajerial yang relevan, serta diskusi mengenai buku The Second Sex Simone de Beauvoir dengan para sarjana. Penelitian ini membahas beberapa cara di mana laki-laki dan perempuan "terletak" dalam wacana perubahan manajemen. Ditemukan bahwa dalam wacana laki-laki manajerial dibangun sebagai "efektif" terhadap perubahan manajemen. Sedangkan perempuan dilimpahkan ke fungsi "afektif" yang mendukungnya. Bahwa hal ini dapat dipahami sebagai perampasan keliyanan perempuan berasal. 
Omair (2009) melakukan penelitian dengan pendekatan kualitatif bertujuan untuk mengeksplorasi bagaimana manajer perempuan di Uni Emirat Arab dapat berperan penting dalam pengembangan karir mereka. Dengan pendekatan narrative dilakukan wawancara secara mendalam terhadap 15 manajer perempuan di Uni Emirat Arab. Penelitian ini menghasilkan tipologi yang membedakan empat jenis pengembangan karir di antara manajer perempuan di Uni Emirat Arab yaitu progresif, moderat, difasilitasi dan idealis. Hasil penelitian ini menunjukkan bahwa status sosial dan hubungan keluarga dapat memainkan peran penting dalam pengembangan karir perempuan.

Wallace (2009) melakukan penelitian terhadap 13 orang Chartered Accountant (CA) perempuan dengan usia berkisar 26-52 tahun yang telah meninggalkan profesi sebagai CA. Dengan pendekatan kualitatif, penelitian ini bertujuan untuk mencari jawaban atas pertanyaan yang bersangkutan dengan pengalaman sosial, khususnya pilihan karir dari CA perempuan. Wallace (2009) menjelaskan dengan menggunakan filsafat feminis eksistensialis Simone de Beauvoir sebagai kerangka kerja teoritisnya ditemukan bahwa para informan memilih profesi akuntansi tanpa tujuan. Wallace (2009) berkesimpulan bahwa secara keseluruhan cerita mengungkapkan bahwa tidak ada satu hal yang mempengaruhi keputusan CA perempuan untuk meninggalkan organisasi kerja atau mengubah pilihan karir mereka. Melainkan ada banyak potensi yang berperan dalam pengambilan keputusan karir, seperti kepentingan pribadi, kepentingan orang lain, kondisi institusi pekerjaan dan peran sebagai seorang ibu. Dengan demikian, filsafat eksistensialis Simone de Beauvoir tidak dapat menjelaskan karir CA perempuan yang menghendaki adanya kebebasan dalam menentukan pilihan terhadap karir.

\subsection{Model Penelitian}

Penelitian ini dilakukan karena terdapat fenomena yang menarik yaitu bahwa sebagian besar perempuan memilih berkarir sebagai akuntan pendidik yaitu $44 \%$ dari jumlah keseluruhan akuntan pendidik. Peneliti melakukan narrative research dengan mewawancarai tujuh perempuan yang berkarir sebagai akuntan pendidik di Jurusan Akuntansi Fakultas Ekonomi dan Bisnis Universitas Tanjungpura, untuk memperoleh gambaran mengenai aspek-aspek apa saja yang membentuk pilihan karir perempuan sebagai akuntan pendidik. Aspek-aspek tersebut meliputi kesempatan (lowongan) pekerjaan, waktu kerja yang fleksibel, latar belakang keluarga, bertemu banyak orang (mahasiswa), cita-cita dari kecil dan sharing ilmu. Dalam menganalisis hasil yang diperoleh dari proses wawancara yang telah dilakukan, cerita-cerita para perempuan tersebut akan dikaitkan dengan perspektif Simone de Beauvoir yang meliputi Women as Other, Independent Women, Institutional of Work dan Institutional of Motherhood. Sehingga dapat diketahui perspektif Simone de Beauvoir tersebut dapat atau tidak dapat menjelaskan pemilihan karir perempuan sebagai akuntan pendidik. Hal ini diperjelas dengan penyajian kerangka model penelitian sebagai berikut: 


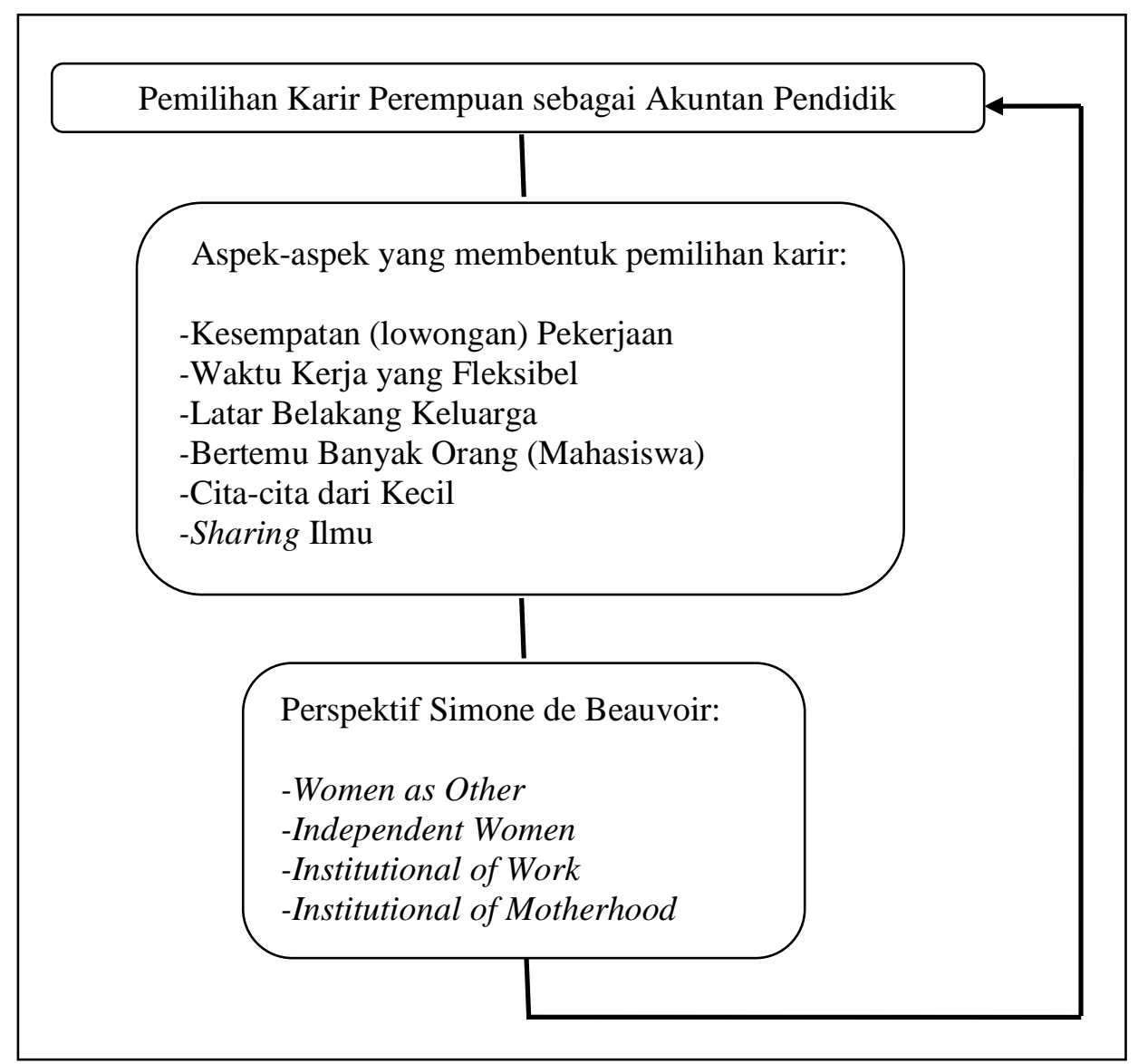

Ket $: \longrightarrow$ Anak panah tidak menunjukkan korelasi, hanya alur berfikir saja.

\section{Gambar 1. Model Penelitian}

\section{METODE PENELITIAN}

\subsection{Desain Penelitian}

Penelitian ini menggunakan pendekatan kualitatif karena penelitian ini berada dalam satu setting tertentu yaitu Jurusan Akuntansi Fakultas Ekonomi dan Bisnis Universitas Tanjungpura Pontianak, yang bermaksud untuk menginvestigasi dan memahami fenomena: apa yang terjadi, mengapa terjadi dan bagaimana terjadinya. Tujuan lainnya adalah memahami suatu situasi sosial, peristiwa, peran, interaksi dan kelompok. Pendekatan kualitatif dalam penelitian ini bertujuan untuk mendiskripsikan aspek-aspek apa saja yang membentuk pemilihan karir perempuan sebagai akuntan pendidik dalam perspektif Simone de Beauvoir. Penelitian ini menggunakan pendekatan fenomenologis sebagai kerangka berpikir utama. Para fenomenolog percaya bahwa pada makhluk hidup, tersedia berbagai cara untuk menginterpretasikan pengalaman melalui interaksi dengan orang lain (Moleong, 2007). Fenomenologi merupakan ilmu yang mempelajari fenomena atau gejala yang dilandasi oleh teori Max Weber (1864-1920). Teori ini menekankan pada metode penghayatan atau pemahaman interpretatif (verstehen). Jika seseorang menunjukkan perilaku tertentu dalam masyarakat, maka 
perilaku tersebut merupakan realisasi dari pandangan-pandangan atau pemikiran yang ada dalam kepala orang tersebut. Kenyataan merupakan ekspresi dari dalam pikiran seseorang; oleh karena itu, realitas tersebut bersifat subjektif dan interpretatif.

Dalam penelitian ini, fenomena yang ingin digali adalah diperolehnya deskripsi sedekat mungkin dengan pengalaman para perempuan yang memilih berkarir sebagai akuntan pendidik daripada profesi lainnya. Pertimbangan lainnya adalah bahwa proses pemilihan karir perempuan sebagai akuntan pendidik merupakan suatu fenomena sosial yang disusun dengan adanya interaksi sosial antara berbagai pihak. Secara khusus, strategi penelitian yang dipilih adalah studi kasus karena merupakan cara yang paling tepat untuk memperoleh pemahaman yang mendalam tentang fenomena (Creswell, 2007; Denscombe, 2003; Yin, 2003). Dalam penelitian studi kasus, Creswell (2007:73) menyatakan bahwa studi kasus merupakan suatu model pendekatan kualitatif yang menekankan pada eksplorasi dari suatu "sistem yang terbatas" (bounded system) pada satu kasus atau beberapa kasus secara mendetail, disertai dengan penggalian data secara

\subsection{Jenis dan Sumber Data}

Dalam penelitian ini data dapat bersumber dari data primer. Pemilihan data primer yang berlokasi di Jurusan Akuntansi Fakultas Ekonomi dan Bisnis Universitas Tanjungpura Pontianak dengan beberapa alasan. Pertama, Universitas Tanjungpura merupakan universitas negeri terbesar yang terdapat di Kalimantan Barat. Kedua, terdapat kesamaan karakteristik, sosial dan budaya antara peneliti dan informan, sehingga timbul kedekatan dan meminimalisir jarak antara peneliti dan informan.

Adapun jumlah subjek penelitian dalam penelitian ini adalah sebelas akuntan pendidik perempuan pada Jurusan Akuntansi Fakultas Ekonomi dan Bisnis Universitas Tanjungpura Pontianak atau sebesar $44 \%$ dari jumlah keseluruhan akuntan pendidik. Penentuan sumber data pada orang yang diwawancarai dilakukan secara purposive, yaitu dipilih dengan kriteria, pertimbangan dan tujuan tertentu. Adapun kriteria akuntan pendidik perempuan yang dijadikan sebagai informan adalah (1) Akuntan pendidik yang sudah menikah, dan (2) Akuntan Pendidik yang memiliki Nomor Induk Pegawai. Dari 11 (sebelas) subjek tersebut, 4 (empat) orang tidak dapat dijadikan sebagai informan karena 1 (satu) orang berprofesi sebagai auditor internal pada BPD Provinsi Kalimantan Barat, 2 (dua) orang yang tidak kawin dan 1 (satu) orang informan tidak dapat diwawancarai karena tidak berada di lokasi penelitian. Sehingga jumlah informan yang akan diwawancarai sebanyak 7 (tujuh) orang.

\subsection{Pengumpulan Data Lapangan}

Data dikumpulkan dengan menggunakan teknik wawancara secara mendalam (indepth interview) kepada informan. Bentuk wawancara yang akan dilakukan adalah wawancara semi-terstruktur dimana isi yang tertulis pada pedoman wawancara berupa topik-topik pembicaraan yang mengacu pada satu tema sentral yang mengacu pada 
perspektif Simone de Beauvoir yaitu Women as Other, Independent Women, Institutional of Work dan Institutional of Motherhood. Dalam melakukan wawancara, peneliti juga membuat catatan rinci mengenai tema-tema penting yang telah diungkapkan informan. Selain itu, untuk mendukung kredibilitas hasil wawancara, wawancara dilakukan dengan dilengkapi dengan alat perekam seperti audio recorder. Hal ini dimaksudkan untuk membandingkan apa yang telah dicatat peneliti tidak jauh berbeda dengan hasil rekaman wawancara, sehingga peneliti benar-benar memberikan laporan yang sebenarnya terjadi di lapangan atau lokasi penelitian. Dengan cara seperti ini kredibilitas data dapat diandalkan.

\subsection{Analisis Data}

Prosedur analisis data dilakukan baik dalam pengumpulan data maupun setelah pengumpulan data selesai. Prosedur yang ditempuh adalah melalui reduksi data (data reduction), sajian data (data display) dan pengambilan kesimpulan (conclusion drawing).

\section{TEMUAN DAN PEMBAHASAN}

\subsection{Aspek-aspek yang Membentuk Pilihan Perempuan untuk Berkarir sebagai}

\section{Akuntan Pendidik}

\section{Kesempatan (lowongan) Pekerjaan}

Beberapa informan memberikan informasi bahwa kesempatan (lowongan) pekerjaan menjadi salah satu aspek yang membentuk pilihan karir mereka sebagai akuntan pendidik. Hal ini dibuktikan dari hasil wawancara dengan salah satu informan. Sebut saja AA, beliau mengatakan:

"Menurut saya, pilihan karir sekarang ini karena kondisi, karena ada kesempatan (lowongan) makanya saya masuk dan menjadi dosen".

Pendapat senada juga diungkapkan oleh BB, beliau mengatakan:

"Sebenarnya sih kalau soal kerjaan ndak milih. Selesai pendidikan S-1 tahun 1997, tahun 1999 saya mengajar di Akademi Manajemen Perusahaan. Selanjutnya, bulan Desember tahun 2000 saya diterima sebagai dosen PNS dan mengajar di Jurusan Akuntansi Fakultas Ekonomi”.

\section{Waktu Kerja yang Fleksibel}

Bagi beberapa orang, bekerja merupakan dasar harga diri dan kebanggaan. Bagi sejumlah orang lainnya bekerja dianggap sebagai prestise yang diperoleh, tempat untuk melakukan partisipasi sosial atau sebagai sumber kesenangan intrinsik atau merupakan ekspresi dari pribadi yang kreatif dan juga merupakan cara memanfaatkan waktu dengan cara yang rutin menyenangkan (Putri, 2012). 
Hal ini dibuktikan dari hasil wawancara dengan salah satu informan. Diantaranya AA yang mengatakan:

"Oh...enak...waktunya lebih banyak, apalagi saya yang tidak punya jabatan apaapa, jadi hanya mengajar saja. Kalau mahasiswa mau konsultasi bisa di rumah. Saya juga paling tidak betah berlama-lama di kampus karena tidak ada yang harus dikerjakan. Kalau misalnya anak sakit, saya tidak masuk dan bisa diganti dengan hari yang lain. Kalau pekerjaan yang lain kan tidak bisa seperti itu. Jadi, waktunya lebih fleksibel".

Lain halnya dengan CC, hambatan dalam berkarir atau bekerja adalah pada saat sudah menikah dan memiliki anak. Pilihan karir sebagai akuntan pendidik adalah lebih tepat untuk mengatasi hambatan tersebut dikarenakan waktunya lebih fleksibel untuk diatur. Hal ini tercermin dalam hasil wawancara dengan beliau berikut ini:

"Itu tadi..karena saya perempuan, nanti saya menikah dan punya anak, saya rasa kalau menjadi dosen waktunya lebih fleksibel saja, tidak terlalu terikat", dimanage dan dikomunikasikan saja".

Keadaan yang serupa juga ditunjukkan oleh DD yang mengatakan lebih mudah mengatur waktu antara keluarga dan pekerjaan. Berikut petikannya:

"Biasanya saya diskusikan dulu kepada suami, jika ada kegiatan berkaitan pekerjaan saya. Kalau sudah tidak ada jam kerja, biasanya saya pulang lebih awal atau pernah juga saya membawa anak ke lingkungan kerja pada saat tidak ada yang menjaganya...jadi fleksibel aja sih...".

Lebih lanjut DD menjelaskan:

"Intinya komunikasi saja sih...kalau anak sakit, saya komunikasikan dulu dengan suami...mungkin bisa gantian menjaga anak...kalau sudah tidak bisa, ya..saya komunikasikan dengan mahasiswa..apakah perlu diganti dengan hari yang lain".

\section{Latar Belakang Keluarga}

Aspek lain yang membentuk pilihan karir perempuan sebagai akuntan pendidik adalah latar belakang keluarga yang pada umumnya berprofesi menjadi guru atau dosen. Begitu juga yang dialami, beliau memutuskan untuk EE berkarir menjadi dosen/pendidik dikarenakan dorongan keluarga, dalam hal ini Ibunda beliau yang juga berprofesi sebagai guru. Berikut petikan wawancaranya:

"Selain itu, latar belakang keluarga banyak yang berprofesi sebagai guru dan tenaga kesehatan. Malahan sekarang, apabila mencari pekerjaan, orientasinya sudah ke arah pendidikan".

EE memberikan penjelasan tambahan berikut ini:

“Apalagi Mama saya backgroundnya adalah seorang guru. Kalau dukungan Mama full ingin saya menjadi pendidik/dosen...”. 
CC memberikan penjelasan yang serupa seperti ini:

"Ya...karena tadi awalnya saya coba ikut tes, memang keputusan saya sendiri. Karena saya terlahir dan berada di lingkungan pengajar. Kakek saya seorang guru, tante saya juga guru. Makanya saat saya memutuskan untuk menjadi dosen, keluarga saya sangat mendukung".

\section{Bertemu Banyak Orang (Mahasiswa)}

Menjadi seorang akuntan pendidik membutuhkan kepribadian yang senang bertemu dengan banyak orang, dalam hal ini mahasiswa. Kepribadian ini dimiliki oleh $\mathrm{BB}$, dimana beliau memaparkan:

"...mungkin enak saja bertemu dengan banyak orang (mahasiswa) dengan kepribadian dan latar belakang yang berbeda-beda".

Holland mengajukan enam tipe kepribadian dasar yang berhubungan dengan karir yaitu intelektual, realistik, sosial, konvensional, enterpise, dan artistik. Tipe sosial cenderung memiliki orientasi menolong. Tipe sosial ini juga sangat sesuai dengan kepribadian DD yang terungkap dalam hasil wawancara berikut ini:

"Saya senang menjadi dosen karena bertemu dengan mahasiswa, karena kalau ketemu ada saja ilmu yang didapat. Dengan menjadi dosen menambah kesenangan saya, walaupun tadinya dari motivasi orang tua, akhirnya saya berusaha menyenangi profesi ini”.

\section{Cita-cita dari Kecil}

Pemilihan karir juga dipengaruhi oleh keyakinan pribadi seseorang. Dalam teori tindakan beralasan (Theory of Reasoned Action/TRA), keyakinan pribadi seseorang adalah faktor penentu penting dari tindakan masa depan (Ajzen, 1991). Minat dan kesenangan yang tertanam dari kecil ini merupakan faktor penentu penting dari tindakan memilih berkarir sebagai akuntan pendidik di masa yang akan datang. Hal ini dibuktikan dari wawancara dengan EE, yang mengatakan:

"Sebenarnya, sewaktu kecil dulu saya bercita-cita ingin menjadi guru, mulai jadi guru TK hingga menjadi Dosen Bahasa Inggris. Sebelum memutuskan kuliah di Fakultas Ekonomi Jurusan Akuntansi ini, banyak tawaran untuk masuk kuliah di berbagai jurusan, di antaranya FKIP, MIPA dan Kedokteran. Pada saat itu, Mama mengatakan kepada saya kalau di Fakultas Ekonomi ada buka jurusan Akuntansi, jika ingin jadi dosen kemungkinan besar bisa di situ".

Selanjutnya, EE menegaskan:

"Yang jelas, dari cita-cita awal (sejak kecil) ndak ada tuh yang komplain ingin jadi guru". 


\section{Sharing Ilmu}

Soemarso (2004) menyatakan akuntan pendidik adalah akuntan yang bertugas dalam pendidikan akuntansi, yaitu mengajar, menyusun kurikulum pendidikan akuntansi dan melakukan penelitian di bidang akuntansi. Hal ini dibuktikan dari wawancara dengan FF yang mengatakan:

"Kalau tidak ada jam mengajar, paling tidak minimal 2 jam saja berada di kampus, setelah itu bebas mau ngapa-ngapain, seperti menulis, research atau lainnya".

Lebih lanjut, EE memberikan penegasan mengenai alasannya berkarir menjadi akuntan pendidik, berikut petikan wawancaranya:

"Selain itu, bisa melakukan apa saja selain mengajar seperti pengabdian pada masyarakat, mau membuat sesuatu yang bermanfaat juga ada, kemudian ada kegiatan penelitian dimana masalah yang akan diangkat menjadi topik penelitian banyak sekali. Ujung-ujungnya banyak manfaat yang saya rasakan apabila menjadi seorang dosen dari pada menjadi profesi lainnya. Makanya, niatnya menjadi seorang dosen karena pengembangan diri lebih oke...lebih bagus dan bisa memberikan manfaat kepada orang lain".

\subsection{Penjelasan Perspektif Simone de Beauvoir terhadap Pemilihan Karir Perempuan sebagai Akuntan Pendidik}

\section{Women as Other}

Secara umum, perempuan yang memilih berkarir sebagai akuntan pendidik sudah menjadi Diri, yaitu subjek yang menjadikan dirinya sebagaimana yang diinginkannya. Hal ini terbutkti dari hasil wawancara dengan para akuntan pendidik perempuan, diantaranya dengan AA, yang mengatakan:

“....semuanya terserah saya, mau saya bekerja atau tidak, semua keputusan di tangan saya. Ya... senangnya saya aja”.

Pendapat yang tidak jauh berbeda juga diutarakan oleh BB, berikut petikannya:

“...Sebenarnya sih kalau soal kerjaan ndak milih...Makanya saya pikir jadi dosen, waktunya lebih mudah ngaturnya...”.

"Kalau saya pribadi, inginnya sih mengajar saja...mungkin ada teman-teman yang lain yang berambisi ingin memperoleh jabatan tertentu, tapi kalau saya cukup mengajar saja...".

Hal senada juga diutarakan oleh EE, dalam wawancaranya beliau mengatakan:

"Sebenarnya, sewaktu kecil dulu saya bercita-cita ingin menjadi guru, mulai jadi guru TK hingga menjadi Dosen Bahasa Inggris. Yang jelas, dari cita-cita awal (sejak kecil) ndak ada tuh yang komplain ingin jadi guru". 
Pendapat yang sama juga diutarakan oleh CC, berikut hasil wawancaranya: “... tahun 2002 ada informasi penerimaan dosen PNS di Untan. Saya coba mengikuti tes tersebut dan Alhamdulillah diterima".

\section{Independent Women}

Seorang perempuan yang memilih untuk bekerja sebagai akuntan pendidik harus mengejar tujuan itu dan tidak hanya mengandalkan tindakan orang lain untuk membantu dia memperoleh hal tersebut. Dari hasil wawancara dengan BB dapat digambarkan makna kebebasan sebagai berikut:

“....memang keinginan saya ingin menjadi dosen dan mendapat dukungan juga dari orang tua dan suami. Berdasarkan apa yang saya alami, saya bebas saja melakukan apa yang saya inginkan dan tentunya harus dengan dukungan suami. Menurut saya, apakah yang kita pilih itu bisa kita sesuaikan dengan kepribadian saya sebagai perempuan. memang kita bebas memilih tapi karena sudah berkeluarga keputusan itu tidak mengganggu keluarga".

Pendapat senada juga diutarakan oleh EE, berikut ini petikan wawancaranya:

"Kebebasan itu kan sebenarnya kita dituntut melakukan apa saja asalkan penuh tanggung jawab".

CC memberikan pendapat yang hampir sama mengenai keputusannya berkarir menjadi akuntan pendidik, hasil wawancaranya berikut ini:

“.... tadi awalnya saya coba ikut tes, memang keputusan saya sendiri. Karena saya terlahir dan berada di lingkungan pengajar. Kakek saya seorang guru, tante saya juga guru. Makanya saat saya memutuskan untuk menjadi dosen, keluarga saya sangat mendukung. Apalagi, kata mereka saya seorang perempuan. Kayaknya lebih pas jadi dosen".

Pendapat yang tidak jauh berbeda juga diutarakan GG, yang mengatakan:

"Keputusan sendiri..yang lain hanya mendukung saja".

\section{Institutional of Work}

Organisasi adalah tempat di mana banyak disebarluaskan image gender yang diciptakan dan direproduksi (Acker, 1990). Asumsi tentang laki-laki dan perempuan telah dimasukkan ke dalam desain pekerjaan (Mills, 1992), menandakan konsepsi tertentu tentang gender (Alvesson dan Billing, 1997). Secara umum para akuntan pendidik perempuan memberikan pendapat yang bertentangan dengan pandangan ini. Hal ini dapat digambarkan dalam hasil wawancara dengan CC berikut ini: 
"Kalau di sini tidak, siapa saja diberikan kesempatan untuk menunjukkan kemampuannya. Tidak peduli apa dia laki-laki atau perempuan. Kalau memang mampu, tidak masalah".

Hal senada juga diungkapkan FF dalam petikan wawancara berikut ini:

"Di lingkungan kerja sih perempuan dan laki-laki sama saja. Yang dilihat bukan dari jenis kelaminnya tapi dari segi kemampuannya, kalau perempuan mampu, kenapa mesti dibedakan dengan laki-laki”.

BB memberikan pendapat yang tidak jauh berbeda, berikut ini paparannya:

“... jadi tidak tepatlah kalau semuanya ditentukan oleh jenis kelamin..siapa saja bisa, sepanjang memang mampu".

Pendapat yang serupa juga diungkapkan GG berikut ini:

“... kalau di lingkungan kerja, selama ini laki-laki dan perempuan tidak pernah dibedakan. Jadi, kalau misalnya ada seminar, ada ibu-ibu mau ikut ya..diberikan rekomendasi. Jadi, tidak mesti laki-laki saja yang keluar".

\section{Institutional of Motherhood}

Selanjutnya, secara tidak langsung Simone de Beauvoir menaruh kecurigaan yang amat sangat besar terhadap lembaga pernikahan dimana ia menganggap bahwa seorang perempuan ketika sudah menikah, ia akan menjadi pihak yang dijadikan objek oleh para kaum pria dan ditindas secara moral. Jika kaum perempuan terlalu bergantung kepada orang lain ataupun kepada kaum laki-laki, hal itu bisa membuat kaum perempuan sendiri merasa menderita dan merasa terpenjara. Pandangan de Beauvoir di atas bertentangan dengan pendapat dari para informan yang merupakan perempuan yang telah menikah dan tetap diberikan kesempatan untuk berkarir menjadi seorang akuntan pendidik. Pendapatpendapat tersebut terangkum dalam hasil wawancara di bawah ini.

Menurut AA, pernikahan tidak menyebabkan kebebasannya dalam menentukan pilihan karirnya menjadi terhambat. Adanya suami justru membuatnya mendapat dukungan. Dalam memutuskan sesuatu dimusyawarahkan, dan hasilnya adalah untuk kepentingan bersama. Berikut petikannya:

"Memang suami adalah imam, dia yang menentukan. Kalau saya, kami selalu bermusyawarah, dan kemudian diperbolehkan. Selama ini sih masih bisa dijalani.

Repot ya repot, asalkan pandai membagi waktu dan mendapat dukungan dari suami, semua tidak masalah".

"Saya merasa tidak terkekang, mau kemana saja boleh. Karena sekarang saya memiliki dua orang anak. Kalau kemana-mana ya..sama anak-anak".

Pandangan de Beauvoir mengacu pada institusi keibuan seperti yang dibentuk oleh masyarakat yang menjadikannya sebagai perangkap, bukan pada tindakan seorang ibu. Pandangan tersebut mendapat pertentangan dari para akuntan pendidik perempuan yang 
juga berperan sebagai seorang ibu. Mereka tidak sependapat dengan de Beauvoir yang mengatakan perempuan sebagai ibu telah menjadi budak bagi anak-anaknya. Hal ini dibuktikan dari wawancara dengan AA, beliau mengatakan:

"Kalau menurut saya sih, itu semua kewajiban. Memang kewajiban seorang Ibu untuk mengurus anak-anaknya. Malah saya enjoy memerankan peran Ibu, apalagi saya tipikalnya orang rumahan. Bagi saya susah kalau tidak memiliki anak. Karena saya bekerja kan untuk anak, bukan lagi diri sendiri yang dipikirkan".

Pendapat senada diungkapkan CC, yang mengatakan:

"Ndaklah..ndak jadi budak. Kalau saya, anak itu anugerah. Anak itu bonus dari Tuhan. Jadi, ya...nikmat saja. Capek sih pasti, kalau bermasalah, setiap orang pasti punya masalah, tidak mesti juga tidak menikah dan tidak memiliki anak tidak bermasalah. Saya menganggap semua itu merupakan kewajiban. Siapa lagi yang akan mengurus mereka kalau bukan kita”.

Lain halnya dengan DD yang menganggap peran seorang ibu dalam melayani dan membesarkan anak-anaknya merupakan wujud dari sebuah rasa kasing sayang. Hal ini tercermin dalam petikan wawancara berikut ini:

"Tidak..saya tidak menganggap diri saya sebagai budak, justru saya merasa apa yang saya berikan kepada anak belum cukup karena saya harus meninggalkan mereka untuk bekerja. Makanya, jika anak saya meminta kompensasi karena saya bekerja, ya saya terima..jadi, peran Ibu dalam mendidik dan membesarkan anak itu luar biasa. Jadi, melayani anak-anak itu merupakan wujud dari sebuah rasa kasih sayang".

FF juga berpendapat bahwa di dalam melayani dan membesarkan anak-anak, seorang ibu telah menunjukkan rasa tanggung jawab yang besar terhadap masa depan anak-anaknya. Hal ini dapat dilihat dari petikan wawancara berikut:

"Kalau saya memandang itu adalah wujud tanggung jawab seorang Ibu untuk mendidik dan membesarkan anaknya. Apalagi aturan agama, sangat memandang tinggi peran seorang Ibu dalam mengasuh anak-anaknya. Jadi, saya tidak setuju kalau dikatakan sebagai budak bagi anaknya. Karena, kalau nanti seorang Ibu sudah tua renta, mungkin gantian anak yang akan memperhatikan orang tua. Jadi, ikhlas saja menjadi seorang Ibu".

\section{KESIMPULAN}

Dari penelitian ini dapat ditarik kesimpulan bahwa aspek-aspek yang membentuk pemilihan karir perempuan sebagai akuntan pendidik di Jurusan Akuntansi Fakultas Ekonomi dan Bisnis Universitas Tanjungpura Pontianak, meliputi kesempatan (lowongan) pekerjaan, waktu kerja yang fleksibel, latar belakang keluarga, bertemu banyak orang (mahasiswa), cita-cita dari kecil dan sharing ilmu. Dari keenam aspek 
pemilihan karir tersebut, aspek kesempatan (lowongan) pekerjaan dan waktu kerja yang fleksibel merupakan aspek yang paling banyak diungkapkan informan dalam memilih berkarir sebagai akuntan pendidik.

Dalam perspektif Simone de Beauvoir dijelaskan bahwa pemilihan karir perempuan sebagai akuntan pendidik meliputi Women as Other, Independent Women, Institutional of Work dan Institutional of Motherhood. Dari keempat perspektif Simone de Beauvoir tersebut, perspektif Women as Other dan Independent Women mampu menjelaskan pemilihan karir perempuan sebagai akuntan pendidik. Sedangkan perspektif Institutional of Work dan Institutional of Motherhood tidak dapat menjelaskan pemilihan karir perempuan sebagai akuntan pendidik di Jurusan Akuntansi Fakultas Ekonomi dan Bisnis Universitas Tanjungpura.

Dalam perspektif Women as Other dan Independent Women, perempuan yang berkarir sebagai akuntan pendidik di Jurusan Akuntansi Fakultas Ekonomi dan Bisnis Universitas Tanjungpura telah menjadi subjek yang mandiri, bebas dan bertanggung jawab dalam memutuskan berkarir sebagai akuntan pendidik. Perspektif Simone de Beauvoir tentang Institutional of Work menyebutkan bahwa di dalam dunia kerja seringkali perempuan dianggap tidak mampu untuk memperoleh kualitas karir sehingga terkadang image gender disebarluaskan di lingkungan kerja. Namun, berbeda halnya di lingkungan Jurusan Akuntansi Fakultas Ekonomi dan Bisnis, Universitas Tanjungpura. Tidak ada pembedaan jenis kelamin, semua diberikan kesempatan yang sama untuk memperoleh kedudukan atau jabatan struktural tertentu. Hanya saja terkadang perempuan sering mengganggap dirinya tidak mampu dan tidak berkeinginan untuk mencapai kemajuan dalam berkarir. Selain itu, senioritas-yunioritas menjadi hambatan kecil dalam mencapai kesuksesan.

Perspektif de Beauvoir mengenai Institutional of Motherhood juga tidak dapat menjelaskan pemilihan karir perempuan sebagai akuntan pendidik. De Beauvoir menganggap pernikahan merupakan perangkap kebebasan diri seorang perempuan dan mempunyai anak merupakan sebagai budak. Namun, berbeda halnya dengan pendapat perempuan sebagai akuntan pendidik di Jurusan Akuntansi Fakultas Ekonomi dan Bisnis Universitas Tanjungpura yang mengganggap bahwa perempuan itu lebih berharga dan berarti jika telah menjadi seorang ibu, bukan dianggap sebagai budak bagi anak-anaknya. Banyak perempuan yang belum diberikan kesempatan menjadi seorang ibu tetap mengusahakan dirinya dapat berperan menjadi seorang ibu misalnya dengan menjadi orang tua asuh atau orang tua angkat.

Adapun keterbatasan dalam penelitian ini adalah dalam penelitian kualitatif, teknik analisis data menggunakan triangulasi. Dalam penelitian ini triangulasi itu tidak dapat dipenuhi. Analisis data hanya dapat dilakukan dengan melakukan wawancara secara mendalam kepada para informan. Selain itu, penelitian ini bersifat kasuistik, sehingga tidak bisa digeneralisasi untuk setting kasus yang berbeda. 


\section{DAFTAR PUSTAKA}

Acker, J. (1992). "Gendering organizational theory", in Mills, A.J. and Tancred, P. (Eds), Gendering Organizational Analysis. Sage, Newbury Park. CA. pp. 248-60.

Ahmadi, M., Helms, M. M., \& Nodoushani, P. (1995). “A Factor-analytic Approach Profilig Job Selection Difference of Male and Female Accountants". Managerial Accounting Journal. Vol. 10 (7): pp. 17-24.

Ajzen, I. (1991). "The theory of planned behavior", Organizational Behavior and Human Decision Processes. Vol. 50: pp. 179-211.

Aminah, M. S. (2010). “Muslimah Career”. Yogyakarta: Pustaka Grahatama.

Ansari, S. \& Euske, K. (1987). "Rational, Rationalizing and Reifying Uses of Accounting Data in Organization". Accounting, Organization and Society. Vol.12 (6).

Ariani, R. (2004). Persepsi Akuntan dan Mahasiswa Akuntansi Terhadap Karir di Kantor Akuntan Publik. Skripsi. Tidak dipublikasikan.

Benny, E., \& Yuskar. (2006). Pengaruh Motivasi terhadap Minat Mahasiswa Akuntansi Untuk Mengikuti Pendidikan Profesi Akuntansi (PPAk). Simposium Nasional Akuntansi IX. Padang.

Cangelosi, J.S., Condi, F., \& Luthy, D. (1985). "The Influence of Introductory Accounting Courses on Career Choice". Accounting Education. Vol. 27 (1): pp. 6068.

Chariri, A. (2006). "The Dynamics of Financial Reporting Practice in an Indonesian Insurance Company: a Reflection of Javaneese Views of an Ethical Social Relationship." Disertasi Tidak Dipublikasikan. School of Accounting and Finance. University of Wollongong.

Cohen, J. R., Pant. L. W., \& Sharp, D. J. (1998). "The effect of Gender and Academy Discipline Diversity on The Ethical Evaluations, Ethical Attention, and Ethical Orientation of Potential Public Accounting Recruits". Accounting Horizon, Vol.12 (3): pp. 250-270.

Colignon, R. \& Covaleski, M. (1988). "An examination of Management Accounting Practice as a Process of Mutual Adjustment". Accounting, Organization, and Society. Vol. 13 (6). 
Creswell, J. W. (2007). Qualitative Inquiry and Research Design, Choosing Among Five Approaches. Second Edition. London: Sage Publications.

De Beauvoir, S. (1956). The Second Sex, Jonathan Cape, London (first published 1949, Trans. H.M.Parshley).

Denscombe, M. (2003). The Good Research Guide for Small-scale Social Research Projects. (2nd ed). Meidenhead: Open University Press.

Ghozali, I. (2007). "Pergeseran Paradigma Akuntansi dari Positivisme ke Perspektif Sosiologi dan Implikasinya terhadap Pendidikan Akuntansi di Indonesia". Jurnal MAKSI, Vol. 7 (1): pp. 50-64.

Gibson, R. L., \& Mitchell, M. H. (1995). Introduction to Counseling and Guidance, Englewood Cliffs - New Jersey : Prentice-Hall Inc.

Grosholz, E. R. (2004). The Legacy of Simone de Beauvoir. Oxford: Clarendon Press.

Hadi, M. L. (2011). "Peran Akuntansi dalam Pasar Modal Global”. Diakses tanggal 9 Juli 2011 dari http://mlukmanhadi.blogspot.com/2011/03/peran-akuntansi-dalampasar-modal.html.

Hastuti, S. (2007). "Perilaku Etis Mahasiswa dan Dosen Ditinjau dari Faktor Individual Gender dan Locus of Control." Jurnal Riset Ekonomi dan Bisnis, Vol. 7 (1): pp.5873.

Milgram, R. M. (1991). Counseling Gifted and Talented Children, Noewood - New Jersey : Ablex Publishing Corporation.

Moleong, L. J. (2007). Metode Penelitian Kualitatif, Bandung: PT. Remja Rosdakarya.

Oktavia, M. (2005). “Analisis Faktor-faktor yang Memotivasi Pemilihan Karier bagi Mahasiswa Akuntansi”. Skripsi. Tidak dipublikasikan.

Omair, K. (2009). “Typology of Career Development for Arab Women Managers in the United Arab Emirates”. Career Development International, Vol. 15 (2): pp. 121143.

Putri, S. A. P. (2012). "Karir dan Pekerjaan di Masa Awal dan Dewasa Madya", Majalah Ilmiah Informatika. Vol.3 (3). September.

Rahayu, S., Sudaryono, E, A., \& Setiawan, D. (2003). "Persepsi Mahasiswa Mengenai Faktor-faktor yang Mempengaruhi Pemilihan Karir", Simposium Nasional Akuntansi VI, Surabaya, 16-17 Oktober, hal. 821-838 
Rasmini, N. K. (2007). "Faktor-faktor yang Berpengaruh pada Keputusan Pemilihan Profesi Akuntan Publik dan Non Akuntan Publik pada Mahasiswa Akuntansi di Bali.” Buletin Studi Ekonomi, Vol. 12 (3) : pp. 351-364.

Regar, M. H. (2003). "Kilas Sorot Perkembangan Akuntansi di Indonesia", Akuntansi Indonesia di Tengah Kancah Perubahan, Jakarta: Pustaka LP3ES.

Setiyani, R. (2005). "Faktor-Faktor Yang Membedakan Mahasiswa Akuntansi Dalam Memilih Profesi Sebagai Akuntan Publik Dan Non Akuntan Publik. (Studi Empiris Pada Mahasiswa Akuntansi Perguruan Tinggi Negeri di Pulau Jawa)". Tesis, Program Studi Magister Sains UNDIP.

Simons, M. A., \& Benjamin, J. (1979). "Beauvoir interview", in Simons, M.A. (1999) Beauvoir and "The Second Sex", Rowman \& Littlefield, Lanham, MD, pp. 1-22.

Simposium Nasional Akuntansi III. (2000). "Kompartemen Akuntan Publik, SNA III". http://sna2000.8m.com/. Diakses tanggal 9 Juli 2011.

Soemarso, S. R. (2004). Akuntansi Suatu Pengantar. Edisi 5. Jakarta: Salemba Empat.

Surya. (1988). Bimbingan Karir. Bandung : PPS UPI. Makalah tidak diterbitkan.

Tong, R. P. (2010). Feminist Thought. Yogyakarta: Jalasutra.

Triyuwono, I. (2000). Organisasi dan Akuntansi Syariah. Yogyakarta: KIS.

Turner. (1986). The Structure of Sociological Theory”. Fourth Edition. Chicago: Dorsey Press.

Twomey, A. M., Linehan, M., \& Walsh, J. S. (2002). "Career Progression of Young Female Accountants: Evidence from the Accountancy Profession in Ireland". Journal of Europen Industrial Training, Vol. 26 (2): pp. 117-124.

Tyler, M. (2005). "Women in Change Management Simone de Beauvoir and the Cooptation of Women's Otherness," Journal of Organizational Change Management, Vol. 18 (6), pp. 561-577.

Wallace, P. (2009). "Career Stories of Women Professional Accountants, Examining the Personal Narratives of Career using Simone de Beauvoir's Feminist Existentialist Philosophy as a Theoretical Framework". Qualitative Research in Organizations and Management: An International Journal, Vol. 4 (1), pp: 62-84.

Yin, R. K. (2003). Case Study Research. Design and Methods (3rd ed.). New Delhi: Sage Publications.s 